Mycobiota and Mycotoxins Associated With Fresh and Dried Grape

\title{
Fruits in Egypt
}

\author{
Khashaba, Reham A. ${ }^{1}$; M.K. Farag ${ }^{1}$; M.A. Al-Geddawy ${ }^{1}$; A.A. Zohri ${ }^{2}$ and \\ W.S. Ragab ${ }^{1}$
}

${ }^{1}$ Food Science and Technology Department, Faculty of Agriculture, Assiut University, Egypt.

${ }^{2}$ Botany and Microbiology Department, Faculty of Science, Assiut University, Egypt.

Received on: $22 / 4 / 2018$

Accepted for publication on: $28 / 4 / 2018$

\section{Abstract}

The aimed to evaluate the extent of contamination of fresh grape, dried grape fruits (raisin) with molds and their mycotoxins. Three hundred and forty five fungal isolates were obtained from 40 samples of fresh fruits (243 isolates) and 30 samples of dried fruits (102 isolates). Twelve fungal genera namely, $\mathrm{Al}$ ternaria, Aspergillus, Cladosporium, Curvularia, Emericella, Fusarium, Geotricum, Gibberella, Mocur, Pinicillum, Rhizopus and Trichoderma were identified from fresh grape samples. All the previous fungal genera except Geotricum and Gibberella were also isolated from dried grape samples. Aspergillus was the most predominant genus followed by Penicillum, Alternaria and Fusarium. Most of the isolated Aspergillus species were found to be positive producers of one or more toxin of aflatoxins and ochratoxin A. Thin layer chromatographic analysis of 14 tested samples of fresh and dried grape showed that one out of four samples of fresh grape was found to be contaminated with aflatoxins $B_{1}$ and $G_{1}$. Meanwhile, 7 out of 10 samples of dried grape were naturally contaminated with ochratoxin A and aflatoxins $\mathrm{B}_{1}, \mathrm{~B}_{2}$ and $\mathrm{G}_{1}$.

\section{Keywords: Fresh grape fruits, Raisin, Aflatoxin, Ochratoxin, Fungi.}

\section{Introduction}

Fresh grape are prone to fungal contamination in the field, during harvesting, transporting, marketing and during storage under domestic conditions. Post-harvest fruit spoilage results in significant economic losses. Additionally, if the spoiling fungi are toxigenic or pathogenic, they could pose a health risk for the consumer. Grape fruit contain high levels of sugars and other nutrients, and they possess an ideal water activity for microbial growth; their low $\mathrm{pH}$ makes them particularly susceptible to fungal spoilage. Some fungi are plant pathogens and can start the spoilage from the field; they proliferate and cause substantial spoilage only after harvest. On the other hand, many fungi can grow at low temperatures and cause substantial damage especially if the grape fruits are stored for extended periods of time. Toxigenic fungi have been isolated from decayed grape fruits. Some of these molds could produce mycotoxins while grown on fruits even during refrigeration. Beside, some molds could cause infections or allergies in susceptible individuals (Tournas and Katsoudas, 2005).

Dried grape fruits (raisin) have become an increasingly attractive snack food because of containing essential amino acid, vitamin, minerals and rich dietary fiber which are beneficial for keeping health (Asghar et al., 2017). According to data from the European commission RASFF, 2015 
(Rapid Alert System for Food and Feed), dried grape fruits and their products have been one of the top safety-patrolled foods as a result of mycotoxin contamination (Miao and Zhou, 2014, Dai et al., 2015 and RASFF, 2015). As for dried grape, mycotoxin contamination has also been perpetually reported (Alghalibi and Shater, 2004, Juan, et al., 2008 and Asghar et al., 2017).

Mycotoxins are fungal secondary metabolites mainly produced by Fusarium spp., Aspergillus spp., Penicillium spp., Claviceps spp., and Alternaria spp., and more than 400 types of mycotoxins have been described (Tolosa et al., 2013). Due to the variable molecular structure of these mycotoxins, these metabolites exhibit a wide range of effects on human health, such as immune suppressive disorders, hormonal teratogenic and mutagenic effects as well as carcinogenic effects on liver and kidney tissues (Pitt, 2013; Rychlik, 2017 and Asam et al., 2017).

Aflatoxins (AF) are the most important mycotoxins in grape products and the $\mathrm{AFB}_{1}$ being the highest carcinogenic natural compound known. The mycotoxins exhibit hepatocarcinogenicity and hepatotoxicity. Acute aflatoxicosis occurs when moderate to high levels are consumed. The disease symptoms may include haemorrhage, acute liver damage, edema, alternation of digestion, absorption and/or metabolism of nutrients and may result in death. The International Agency for Research on Cancer (IARC) has classified AF as groupI carcinogens (Varga et al., 2015). These mycotoxins are pro- duced predominantly by $A$. flavus and $A$. parasiticus (Paterson and Lima, $2010 \mathrm{a}$ and $\mathrm{b}$ and Paterson et al., 2014).

Ochratoxin A (OTA) is a widespread mycotoxin in grape products that is produced by several Aspergillus and Penicillium species (GilSerna et al., 2011). The OTA is a cyclic, chlorinated pentaketidedihydroisocoumarin derivate linked to L- $\beta$ phenylalanine by an amide bond, which has been detected from many agricultural products. Several nephropathies affecting animals and humans have been attributed to OTA. (Varga et al., 2015). It is widely known that OTA presence in raisins is closely related to fungal contamination in the vineyards. Many studies have been performed to unravel the most important ochratoxigenic species occurring in grape. Several reports evidenced the contribution of Aspergillus section Nigri species to OTA contamination of grape and their occurrence on the surface of healthy berries (Cabañes et al., 2002). However, their prevalence differs depending on the geographical region where the grapes are cultivated (Varga et al., 2006). In general, $A$. carbonarius is considered as the most important ochratoxigenic species in grape due to its common occurrence and its high production ability (almost all of the strains are able to produce the toxin at different levels).

Thus, The study aimed to evaluate the contamination extent of fresh and dried grape fruits (raisin) with molds and their mycotoxins. The ability of the isolated fungi to produce mycotoxins was also studied. 


\section{Materials and Methods}

\section{Collection of samples}

Forty samples of fresh grape and thirty samples of dried grape (raisin) were collected from different markets of several locationsat Assiut governorate, Egypt. Each sample was put in a sterilized polyethylene bag, sealed and put in another bag which was also sealed to minimize the loss of water content and give sufficient aeration. All samples were transferred immediately to the laboratory and kept in a refrigerator $\left(3-5^{\circ} \mathrm{C}\right)$ till microbiological and mycotoxin analysis.

\section{Isolation and identification of fungi}

Fungi were isolated using the dilution plate method as described by Tournas et al., (2006). Using 20\% sucrose-Czapek's agar medium containingchloramphenicol $(20 \mu \mathrm{g} / \mathrm{ml})$ as bacteriostatic agent. The plates were incubated at $28^{\circ} \mathrm{C}$ for 10 days and the developing fungi were counted, isolated and identified based on their macro- and microscopic characteristics using the following references: (Reper and Fennell, 1965, Ainsworth, 1971, Ellis, 1976, Booth, 1977, Pitt, 1979, Klich and Pitt, 1992, Moubasher, 1993, and Pitt and Hocking, 2009).

\section{Mycotoxins analysis}

Testing the toxicity of the isolated molds

A total of 10 different isolates of filamentous fungi from different samples during the first part of this study belonging to Aspergillus spp (8 isolates) and Penicillum spp (2 isolates) were examined for their ability on mycotoxins production. Each individual fungal isolate was cultivated on liquid medium (5g difco myco- logical peptone, $20 \mathrm{~g}$ yeast extract, $40 \mathrm{~g}$ sucrose in 1 liter deionized water " $\mathrm{pH}$ 5.5"). Erlenmeyer flasks of 250 $\mathrm{ml}$ capacity were used. Each flask contained $50 \mathrm{ml}$ medium. The flasks were sterilized at 1.5 atmosphere for 20 min and inoculated after cooling with two $\mathrm{ml}$ of the inoculum suspension of 10 days old culture of the pure organism. The culture were incubated at $28^{ \pm \circ} \mathrm{C}$ as static cultivation for 10 days (Dorner et al., 1984). The extraction and determination of the released mycotoxinswas carried out according to the method of AOAC (1980).

\section{Extraction of mycotoxins}

Fifty grams of each fruit sample were transferred into blender jar and $100 \mathrm{ml}$ chloroform were added. The contents were homogenized for 5 minutes at low speed and 3 minutes at high speed. The extract was filtered through filter paper. The extraction procedure was repeated twice with the same volume of chloroform. The combined chloroform extracts were washed with equal volume of distilled water, dried over sodium sulphateanhydrous and then evaporated to near dryness on steam bath. The residue was transferred quantitatively to a small vial with $1 \mathrm{ml}$ chloroform.

\section{Mycotoxins detection}

Mycotoxins extracted from grape fruits tissue and fungal isolates cultures were determined by thin layer chromatographic technique on pre-coated silica gel plate 60 F254 (Merck) as described by El-Kady and Moubasher (1982). Mycotoxins were identified by comparison with appropriate reference standards of mycotoxins using solvent system of chloroform: acetone $(90: 10, \mathrm{v} / \mathrm{v})$ for 
Aflatoxins and toluene: ethylacetate: $90 \%$ formic acid $(6: 30: 10, \mathrm{v} / \mathrm{v} / \mathrm{v})$ for ochratoxins.

\section{Chemical confirmatory tests for mycotoxins}

Additional confirmatory tests were needed to differentiate unambiguously between the mycotoxins and other fluoresces compounds which may be present in an extract. Chemical confirmatory tests for positive samples was carried out using various treatments on TLC plates in accordance with the method of Golinski and Grabarkiewica-szczesna(1984).

\section{Results and Discussion}

Occurrence and percentage of fungal frequency isolated from fresh and dried grape fruits.

A survey study was conducted on 40 samples of fresh grape and 30 samples of dried grape (raisin) which collected from shops and markets of different locations at Assiut governorate, Egypt.

Isolation of fungi contaminated fresh and dried grape resulted in collecting of 345 fungal isolates (243 isolates from fresh and 102 fungal isolates from dried grape). Data in Table (1) show that, twelve fungal genera namely; Alternaria, Aspergillus, Cladosporium, Curvularia, Emericella, Fusarium, Geotricum, Gibberella, Mocur, Pinicillum, Rhizopus and Trichoderma were identified from fresh grape samples. All the previous fungal genera except Geotricum and Gibberella were also isolated from dried grape samples. Data in the same Table showed that, Aspergillus was the most frequently occurring genus which record 40 isolates with frequency occurrence $100 \%$ in fresh fruits and 26 isolates with frequency occurrence $86.7 \%$ in dried fruits. Penicillum was the second predominant genus which recorded frequency of $92.5 \%$ in fresh fruits and $56.7 \%$ in dried fruits. $\mathrm{Al}-$ ternaria and Fusarium were moderate fungal frequency occurred in fresh and dried samples of grape. Cladosporium, Emericella, Mocur, Trichoderm and Ulocladium were less fungal frequency occurred in all grape samples.

Similar results were obtained by several studies (Magnoli et al., 2004, Tournas and Katsoudas, 2005, Alisa et al., 2007, Fredj et al., 2007 and Alghalibi et al., 2008). The data of Alisa et al.(2007) obtained from the grape samples revealed a high diversity (812 isolates) of fungal genera including Aspergillus spp., B. cinerea, Alternaria spp., Penicillium spp., Cladosporium spp., Sphaeropsis spp., Trichoderma spp., Rhizopus spp., Epicoccum spp. and Fusarium spp. Al-Ghalibi et al. (2008) reported that prevalence of Aspergillus and Penicillum on dry raisins, Fusarium, Cladosporium, Emericella and Mocur were less frequently isolated.

During maturation, the spoilage agents, Aspergillus, Penicilliumand Rhizopus, increase their incidence. When the temperature is higher than $37^{\circ} \mathrm{C}$, species in Aspergillus section Nigri, usually called black Aspergilli become predominant (Valero et al., 2005). At harvest time, the conditions are optimal for fungal invasion, especially if physical damage had occurred on grape. After harvest, grape is subjected to different processes, depending on the intended use.

Grapes can be eaten fresh, dried by sunlight for raisin production. 
Each of these treatments is characterized by contamination with different fungal species. Both grape form for table consumption, are mainly contaminated in the field by Aspergillus, Botrytis, and Penicillium species, which often can be isolated from symptomless berries (Battilani and Pietri, 2002), and successively by black Aspergilli and Botrytis cinerea in post-harvest cold storage (Guzev et al., 2008).

On dried fruits as well, Aspergillus and Penicillium species are often present (Valero et al., 2005); in particular the predominance of $A s$ pergillus species on dried fruits is reported worldwide, including Italy, Spain (Abarca et al., 2003), Brazil
(Iamanaka et al., 2005), Argentina (Da Rocha Rosa et al., 2002), and California (Palumbo et al., 2011). Determination of the mycobiota occurring on grape fruits at the different stages of growing and processing is important to establish an adequate program of treatments for the prevention of fungal contamination in the vineyard and storage. Some of the fungal species occurring on grape and their products can produce mycotoxins, so species identification is critical to predict the potential mycotoxin contamination of grape and raisin. Certainly the Aspergillus species are present worldwide, in all the grape products and under all environmental conditions.

Table 1. Number of case of isolations (NCI), frequency percent (F \%), occurrence remarks $\left(\mathrm{OR}^{*}\right)$ and species number $(\mathrm{SN})$ of each of the isolated fungal genera

\begin{tabular}{|l|c|c|c|c|c|c|c|c|}
\hline \multirow{2}{*}{ Genera } & \multicolumn{4}{|c|}{ Grape fruit 40 samples } & \multicolumn{4}{c|}{ Raisin 30 samples } \\
\cline { 2 - 9 } & SN & NCI & F\% & OR* & SN & NCI & F\% & OR* \\
\hline Alternaria & 1 & 20 & 50 & H & 1 & 7 & 23 & M \\
\hline Aspergillus & 20 & 40 & 100 & H & 20 & 26 & 86.7 & $\mathrm{H}$ \\
\hline Cladosporium & 1 & 16 & 40 & $\mathrm{M}$ & 1 & 8 & 26.7 & $\mathrm{M}$ \\
\hline Curvularia & 1 & 14 & 35 & $\mathrm{M}$ & 1 & 6 & 20 & $\mathrm{~L}$ \\
\hline Emericella & 1 & 18 & 45 & $\mathrm{M}$ & 1 & 14 & 46.7 & $\mathrm{M}$ \\
\hline Fusarium & 1 & 22 & 55 & $\mathrm{H}$ & 1 & 6 & 20 & $\mathrm{~L}$ \\
\hline Geotrichum & 1 & 9 & 22.5 & $\mathrm{~L}$ & - & 0.0 & 0.0 & 0.0 \\
\hline Gibberella & 1 & 15 & 37.5 & $\mathrm{M}$ & - & 0.0 & 0.0 & 0.0 \\
\hline Mucor & 1 & 14 & 35 & $\mathrm{M}$ & 1 & 4 & 13 & $\mathrm{~L}$ \\
\hline Pinicillum & 10 & 37 & 92.5 & $\mathrm{H}$ & 5 & 17 & 56.7 & $\mathrm{H}$ \\
\hline Rhizopus & 1 & 24 & 60 & $\mathrm{H}$ & 1 & 10 & 33 & $\mathrm{M}$ \\
\hline Trichoderma & 1 & 14 & 35 & $\mathrm{M}$ & 1 & 4 & 13 & $\mathrm{~L}$ \\
\hline Total & 40 & $\mathbf{2 4 3}$ & - & - & 33 & $\mathbf{1 0 2}$ & - & - \\
\hline
\end{tabular}

*OR= Occurrence remark:

-For grape fruit samples: $\mathrm{H}=$ high, between $20-40$ cases (out of 40 ); $\mathrm{M}=$ moderate, between 1019 cases; $\mathrm{L}=$ low, between 5-9 cases; $\mathrm{R}=$ rare, $4-1$ cases.

-For raisin samples: $\mathrm{H}=$ high, between $15-30$ cases (out of 30 ); $\mathrm{M}=$ moderate, between 7-14 cases; $\mathrm{L}=$ low, between $3-6$ cases; $\mathrm{R}=$ rare, 1 or 2 cases.

The isolated fungi ability to produce mycotoxins.

A total of 10 different isolates of filamentous fungi isolated from different samples during the first part of this study belonging to Aspergillus
(8 isolates) and Penicillum (2 isolates) were examined to assess their ability on mycotoxins production. Data recorded in Table (2) showed that, all the examined isolates of $A s$ pergillus except $A$. niger proved to be 
positive producers of mycotoxins. Data also indicated that, two Aspergillusflavus isolated from dried and fresh grape samples produced aflatoxin $\mathrm{B}_{1}$ and aflatoxins $\mathrm{B}_{1}$ plus $\mathrm{B}_{2}$, respectively. While $A$. parasiticus isolated from fresh grape samples produced aflatoxins $\mathrm{B}_{1}, \mathrm{~B}_{2}, \mathrm{G}_{1}$ and $\mathrm{G}_{2}$. Also, anisolate of A. awamori isolated from raisin samples showed positive reaction for aflatoxin $\mathrm{B}_{1}$ production. Toxigenic strains of $A$. flavus, A. parasiticus and A. awamorii forming aflatoxins were found in fresh grape and products from grape (raisin) by many investigators (Antonio et al., 2003, Heperkan, 2006, Alghalibi et al., 2008, Barkai and Paster, 2008 and Karbaneoglu and Heperkan, 2009).

Data in Table (2) revealed that, two A.carbonarius and one isolate of A.ochraceus had the ability to produce ochratoxin A. On the other hand, no mycotoxin was formed by the examined two Penicillum species (P.citrinum and P.glabrum) isolated from samples of fresh and dried grape. Toxigenic strains of $A$. carbonarius and ochratoxin A were often found associated with black rot of grape (Antonio et al., 2003). A survey carried out in Lebanon also reported that A. carbonarius was the most important OTA producer in dried grape reaching $100 \%$ of producing isolates (El Khoury et al., 2008).
Similar results were obtained by Fredj et al. (2009) who reported, $A$. carbonarius and A.ochraceus represented an important risk for OTA contamination with more than $80 \%$ of producing strains isolated from raisin. Garmendia and Vero (2016) reported that, all $A$. carbonarius isolates from grape fruits and their products had the ability to produce OTA.

However, mycotoxigenic fungi are spread on grape fruits during fruit growth, ripening and at especially during the ripening and over ripening phase. The formation of mycotoxinsin dried grape is mainly due to contamination by Aspergillus species and particularly A. flavus and A. parasiticus. Thus, toxigenic fungi may grow and form mycotoxinson the outer surface or inside the cavity even if no damage occurs on the skin. The critical periods for aflatoxin formation in dried grape fruits starts with grape ripening on the tree, continues during the over-ripe period when they lose water, shrivel and fall down onto the ground and until they are fully dried on drying trays. Some insect pests that are active at fruit ripening stage may act as vectors in transferring the mycotoxigenic fungi to the fruit cavity (CAC/RCP65, 2008). However, Current concerns mostly apply to mycotoxins (Aflatoxins and Ochratoxin A) contamination in grapes and their products (Li et al., 2017). 
Table 2. Mycotoxins formation by some fungi isolated from fresh and dried grape fruit samples.

\begin{tabular}{|c|c|c|c|c|}
\hline \multirow{2}{*}{ Type of Mycotoxins } & \multicolumn{2}{|c|}{ Source of isolation } & \multirow{2}{*}{ Fungal species } & \multirow{2}{*}{ Fungal Genera } \\
\hline & Dry grape & Fresh grape & & \\
\hline Aflatoxin $\mathrm{B}_{1}$ & + & - & A.flavus & \multirow{8}{*}{ Aspergillus } \\
\hline Aflatoxins $\mathrm{B}_{1}, \mathrm{~B}_{2}, \mathrm{G}_{1} \& \mathrm{G}_{2}$ & - & + & A.parasiticus & \\
\hline Aflatoxins $\mathrm{B}_{1} \& \mathrm{~B}_{2}$ & - & + & A.flavus & \\
\hline Aflatoxin $\mathrm{B}_{1}$ & + & - & A.awamorii & \\
\hline Ochratoxin A & - & + & A.carbonarius & \\
\hline Ochratoxin A & + & - & A.carbonarius & \\
\hline Ochratoxin A & + & - & A.ochraceus & \\
\hline- & + & - & A.niger & \\
\hline- & - & + & p.citrinum & \multirow{2}{*}{ Penicillum } \\
\hline- & + & - & p.glabrum & \\
\hline
\end{tabular}

Natural occurrence of mycotoxins in fresh grape fruits and raisin samples.

As shown in Table (3), thin layer chromatographic analysis of 14 tested samples (10 raisins samples) and 4 fresh grape fruits samples, showed that $8 / 14$ positive samples were found to be contaminated with mycotoxins; 7 of raisin and one sample of fresh grape fruits were naturally contaminated with mycotoxins.

Results in Table (3) indicated that aflatoxins were detected in four samples $(40 \%)$ of raisin and one sample $(25 \%)$ of fresh grape fruits. Also, ochratoxin A was found in three out of the ten samples of raisin $(30 \%)$. Similar results were recorded by Luttfullah and Hussain (2011) who detected aflatoxins in raisin samples and found contamination in $25 \%$ of the tested samples. Another study also revealed that $48 \%$ of 110 raisin samples analyzed for ochratoxin A were contaminated (Heperkan, 2008). According to Varga and Kozakiewicz (2006), ochratoxin A contamination of dried grape is usually much higher than that of grape fruits. Formation of OTA in raisin is mostly considered to be a post-harvest problem and around $50 \%$ of the A. carbonarius contamination occurred during the first to the second week of sun-drying stage (Magan and Aldred, 2005).

The obtained results are similar with Özay and Alperden (2005) examined 103 samples collected from various orchards and at various stages of grape processing, including samples of dried grape. Overall, aflatoxins $B_{1}, B_{2}, G_{1}$, and $G_{2}$ were present in $29 \%$ of the samples. Ochratoxin A was detected in only $3 \%$ of the samples. In samples collected during the sun drying of grape, only aflatoxin $\mathrm{B}_{1}$ and $\mathrm{G}_{1}$ were detected.

The high concentration of sugar and low water activity during the drying process creates a very suitable and selective environment for these fungi to grow in dried fruits due to the fact that the molds belonging to the Aspergillus and Penicillum are xerotolerant (Abarca et al., 2003 and Samson et al., 2006). 
Table 3. Natural contamination of fresh and dried grape fruits with mycotoxins.

\begin{tabular}{|c|c|c|c|}
\hline Kind of mycotoxins & No. + vesamples & No. tested samples & Samples grape \\
\hline $\begin{array}{c}\text { Aflatoxin } \\
\mathrm{B}_{1} \text { and } \mathrm{G}_{2}\end{array}$ & 1 & 4 & Fresh fruits \\
\hline $\begin{array}{c}\text { Aflatoxin } \\
\mathrm{B}_{1}, \mathrm{~B}_{2} \text { and } \mathrm{G}_{1} \\
\text { Ochratoxin } \mathrm{A}\end{array}$ & 4 & 10 & Dried fruits (raisin) \\
\hline- & 3 & & Total samples \\
\hline
\end{tabular}

\section{Conclusion}

The present work indicated that the examined fresh and dried grape fruits were contaminated with several fungi especially members of Aspergillus and Penicillium. Many of these fungi are capable of producing mycotoxins such as aflatoxins and ochratoxin A. These findings indicate that there may be a risk of human exposure to mycotoxins through the consumption of grape fruits. So, strict hygiene microbiological must be applied during different stages of harvest, transport, storage, drying and handling to avoid the harmful effects on human health.

\section{Referance}

AOAC, (1980). Association of Official Agricultural Chemists. Official Methods of Analysis, $12^{\text {th }}$ ed., P. O. Box 450, Benjamin Franklin station, Washington, D.C., pp: 832.

Abarca M.L., F. Accensi, M.R. Bragulat, G. Castella and F.J. Cabanes, (2003). Aspergilluscarbonarius as the main source of ochratoxin A contamination in dried wine fruits from the Spanish market. J. of Food Protection 66, 504-506.

Ainsworth GC (1971). Ainsworth and Bishy's Dictionary of fungi: (P. 412) Commonwealth Mycological Institute, Kew, Surry, England.

Alghalibi, S. M., and Shater, A. R. M. (2004). Mycoflora and mycotoxin contamination of some dried fruits in Yemen Republic. Assiut Uni- versity Bulletin for Environmental Researches, 7(2), 19 - 27.

Alghalibi, S., M. Battah and M. AlZubairy, (2008). Fungal contamination and aflatoxinsconteny of dry raisins fruits in Sanaa City, Republic of Yamen. Arabian Gulf Univ. Bahrain. 26: 1/2, 41-48.

Alisa, D., L. Su-lin, A. Benozir, W. Robert and S. Eileen, (2007). Fungi and mycotoxins in vine tards and grape production. International Journal of Food Microbiology, 119, $1-2,84-88$.

Antonio, L., B. Antonio, M. Guseppina, M. Antonio and P. Giancalo, (2003). Epidemiology of toxigenic Fungi and their associated mycoyoxins for some mediterranean crops. European J of Plant Pathology, 109(7), 645-667.

Asam, S., Habler, K., and Rychlik, M, (2017). Fusariummycotoxins in food. In D. Schrenk, and A. Cartus (Eds.), Chemical contaminants and residues in food $\left(2^{\text {th }}\right.$ ed., $p$. 295e336). Duxford: Academic Press.

Asghar, M. A., Ahmed, A., Zahir, E., Asgher, M. A., Iqbal, J., and Walker, G, (2017). Incidence of aflatoxins contamination in dry fruits and edible nuts collected from Pakistan. Food Control, 78, $169 \mathrm{e} 175$.

Barkai, G.R. and N. Paster, (2008). Moldy fruits and vegetables as a source of mycotoxins: Part 1. World Mycotoxin, 1(2), 147-159. 
Battilani P. and A. Pietri, (2002). Ochratoxin $\mathrm{A}$ in grapes and wine. European of Plant Pathology 108, 639-643.

Booth, C,(1977). Fusarium laboratory guide to the identification of the major species. (P. 58) Commonwealth Mycological Institute, Kew, Surrey, England.

Cabañes, F.J.; Accensi, F.; Bragulat, M.R.; Abarca, M.L.; Castellá, G.; Minguez, S.; Pons, A,(2002). What is the source of ochratoxinA in wine Int. J. Food Microbiol., 79, 213-215.

CAC/RCP 65- (2008). Code of practice for the prevention and reduction of aflatoxin contamination in dried figs. pp: 1-7.

Da Rocha Rosa C.A., V. Palacios, M. Combina, M.E. Fraga, A. De Oliveira Reckson, C.E. Magnoli and A.M. Dalcero, (2002). Potential ochratoxinA producers from wine grapes in Argentina and Brazil. Food Additives and Contaminants 19, 408-414.

Dai, Y., Li, Q., Liu, W., Liu, A. L., and Liu, P,(2015). Analysis on China food safety by notifications of EU Rapid Alert System for Food and Feed (RASFF) in 2014. Food Research and Development, 36(22), $177-180$.

Dorner B.T., M.H. Taniwaki, H.C. Menezes, E. Vicente and M.H.P. Fungano, (1984). Incidence of toxigenic fungi and ochratoxin $\mathrm{A}$ in dried fruits sold in Brazil. Food Additives and Contaminants, Part A 22 (12), 1258-1263.

El Khoury, A.; Rizk, T.; Lteif, R.; Azouri, H.; Delia, M.L.; Lebrihi, A, (2008). Fungal contamination and aflatoxin $B_{1}$ and ochratoxin $A$ in Lebanese wine-grapes and musts. Food Chem. Toxicol., 46, 2244-2250.
El-Kady, I.A. and A.H, Moubasher, (1982). Toxigenicity and toxin of Stachybotryschartarum isolates from wheat straw samples in Egypt. Experimental Mycology 6: $25-31$.

Ellis, M.B. (1976). More Dematiaceous Hyphomycetes.(p. 507) Common wealth Mycological Institute, Kew, Surrey, England. EU market for dried fruit. CBI Market Information Database. http://www.icci.com.pk/data/down loads/1/131919889_1.pdf.

Fredj, S., S. Chebil, A. Lebrihi, S. Larsam, A. Gohrbel and A. Miliki, (2007). Occurrence of pathogenic fungal species in Tunisian vineyards. Inte $\mathrm{J}$ of Food Microbio, 113(3), 245-250.

Fredj, S.M.; Chebil, S.; Mliki, A, (2009). Isolation and characterization of ochratoxin $\mathrm{A}$ and aflatoxin $\mathrm{B}_{1}$ producing fungi infecting grapevines cultivated in Tunisia. Afr. J. Microbiol. Res., 3, 523-527.

Garmendia, G., and Vero, S,(2016). Occurrence and biodiversity of $A s$ pergillus section Nigri on "Tannat" grapes in Uruguay. International Journal of Food Microbiology, 216, 31-39.

Gil-Serna, J.; Vázquez, C.; Sardiñas, N.; González-Jaén, M.T.; Patiño, B, (2011). Revision of ochratoxin A production capacity by the main species of Aspergillus section Circumdati. Aspergillussteynii revealed as the main risk of OTA contamination. Food Control. 22, 343-345.

Golinski, P. and Grabarkiewicaszczesna, j, (1984). Chemical confirmatory tests for ochratoxin A, citrinin, penicillic acid, sterigmatocystin and zearalenone performed directly on thin layer chromatographc plates. J. Assoc. Off. Anal. chem., 67, 1108-1110. 
Guzev L., A. Danshin, T. Zahavi, A. Ovadia and A. Lichter, (2008). The effects of cold storage of table grapes, sulphur dioxide and ethanol on species of black Aspergillus producing ochratoxin $\mathrm{A}$. Inter $\mathrm{J}$ of Food Sci and Techn 43, 1187-1194.

Heperkan, D., (2008). The importance of mycotoxins and a brief history of mycotoxin studies in Turkey. ARI Bulletin of Istanbul Technical Univ. 54, 18-27 (Special issue Mycotoxins: hidden hazard in food).

Heperkan, D., (2006). The importance of mycotoxins and a brief history of mycotoxin studies in Turkey. ARI Bulletin of Istanbul Technical Univ. 54, 18-27 (Special issue Mycotoxins: hidden hazard in food).

Iamanaka B.T., M.H. Taniwaki, H.C. Menezes, E. Vicente and M.H.P. Fungano, (2005). Incidence of toxigenic fungi and ochratoxin A in dried fruits sold in Brazil. Food Additives and Contaminants, Part A22 (12), 1258-1263.

Juan, C., Zinedine, A., Molto, J. C., Idrissi, L., and Manees, J, (2008). Aflatoxins levels in dried fruits and nuts from Rabat-Sal_e area, Morocco. Food Control, 19(9), $849 \mathrm{e} 853$.

Karbaneoglu, G.F. and D. Heperkan, (2009). Natural occurrence of fumonisin B1 in dried figs as an unexpected hazard. Food and Chemical Toxicology,47(2): 289-292.

Klich, M.A. and Pitt, J.I, (1992). A laboratory guide to the common $A s$ pergillus species and their teleomorphs. Common Wealth Scientific and Industrial Research Organization, Division of Food Processing, North Ryde, Australia.

Li, Z. X., Nie, J. Y., Yan, Z., Zhang, X. N., Guan, D. K., and Shen, Y. M,
(2017). Progress in research of detection, risk assessment and control of the mycotoxins in fruits and fruit products. Scientia Agricultura Sinica, 50(2), 332 - 347.

Luttfullah, G., and Hussain, A.(2011). Studies on contamination level of aflatoxins in some dried fruits and nuts of Pakistan. Food Control, 22(3), 426 - 429.

Magan, N. and Aldred, D.(2005). Conditions of formation of ochratoxin A in drying, transport and in different commodities. Food Additives and Contaminants 22 (Suppl. 1), 1016. Magnnoli, C., A. Astoreca, L. Ponsone, M. Combina, G. Palacio, C. Rosa and A. Dalcero, 2004.

Magnnoli, C., A. Astoreca, L. Ponsone, M. Combina, G. Palacio, C. Rosa and A. Dalcero, (2004). Survey of mycoflora and ochratoxinA in dried vine fruits from Argentina markets. Letters in Applied Microbiology, 39, 326-331.

Miao, T. S., and Zhou, Q. J,(2014). Empirical study on food safety of EU RASFF database $\mathrm{J}$ of Food Sci \& Tech, 32(2), 76 - 82.

Moubasher, A.H,(1993). Soil fungi in Qatar and other Arab countries. Published by the Scientific and Applied Research Center, University of Qatar.

Özay, G. and Alperden M,(2005). Influence of harvesting and drying technique on mycoflora and mycotoxins of dried grape. Nahrung, 39:156-165.

Palumbo J.D., T.L. O'Keeffe, S.J. Vasquez and N.E. Mahoney, (2011). Isolation and identification of ochratoxin A-producing Aspergillus section Nigristrains from California raisins. Letters in Applied Microbi, 52, 330-336.

Paterson, R. R. M., and Lima, N, (2010a). How will climate change 
affect mycotoxins in food. Food Research Inter, 43, 1902-1914.

Paterson, R. R. M., and Lima, N, (2010b). Toxicology of mycotoxins. EXS, 100, 31-63.

Paterson, R. R. M., Lima, N., and Taniwaki, M. H.(2014). Coffee, mycotoxins and climate change. Food Research Inter, 61, 1-15.

Pitt, J. I.,(2013). Mycotoxins. In J. G. Morris, and M. E. Potter (Eds.), Foodborne infections and intoxications ( $4^{\text {th }}$ ed., pp. 409e418). San Diego: Academic Press.

Pitt, J. I. and Hocking, A. D.,(2009). Spoilage of stored, processed and preserved foods. In: Fungi and Food Spoilage. $3^{\text {rd }}$ ed. Springer Science Business Media, New York, USA.

Pitt, J.I. (1979). The genus Penicullium and its teleomorphic states Eupenicillium and Talaromyces. (p. 634) Academic Press. Inc. (London).

Raper, K.B. and Fennel, P.I,(1965). The genus Aspergillus (p. 686) Williams and Wilkins Baltimore U.S.A.

RASFF, (2015). The rapid alert system for food and feed. Annual report 2014. European commission. Retrieved April 4, 2016, from http://ec.europa.eu/food/ safety/rasff.

Rychlik, M. (2017). Mycotoxins except Fusarium toxins in foods. In D. Schrenk, and A. Cartus (Eds.),
Chemical contaminants and residues in food ( $2^{\text {th }}$ ed., pp. 279e294). Duxford: Academic Press.

Samson, R.A., Hong, S., Frisvad, J.C., (2006). Old and new concepts of species differentiation in Aspergillus. Medical Mycology. 44, 133148.

Tolosa, J., Font, G., Ma nes, J., and Ferrer, E. (2013). Nuts and dried fruits: Natural occurrence of emerging Fusarium mycotoxins. Food Control, 33(1), 215 - 220.

Tournas, V.H., Heeres, J. and Burgess, L,(2006). Moulds and yeasts in fruit salads and fruit juices. Food Microbiology 23, $684-688$.

Valero A., S. Marín, A.J. Ramos, A.J. and V. Sanchis, (2005). Ochratoxin A-producing species in grapes and sun-dried grapes and their relation to ecophysiological factors. Lettersin Applied Microbiology 41, 196-201.

Varga, J., Kozakiewicz, Z., (2006). Ochratoxin A in grapes and grapederived products. Trends in Food Scie and Techn 17, 72-81.

Varga, V., Kocsubé, S., Szigeti, G., Baranyi, N., and Tóth, B, (2015). Aspergillus mycotoxins. In R. R. M. Paterson, \& N. Lima (Eds.). Molecular biology of food and water borne mycotoxigenic and mycotic fungi (pp. 165-186). Baton Rouge: CRC Press. 
الفطريات و السموم الفطرية المرتبطة بثمار العنب الطازجة و المجفقة في مصر

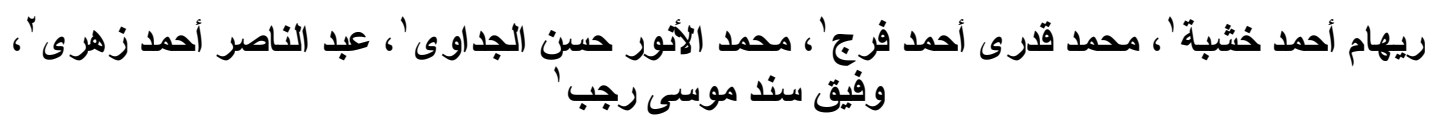

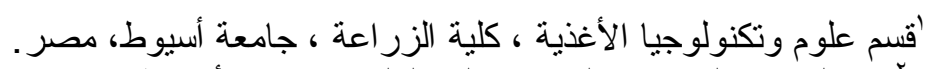

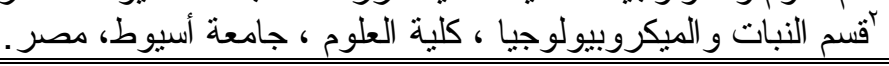

يهدف هذا البحث إلي تقييم ددى تلوث ثمـار العنب الطازجة و المجففة (الزبيب) بالفطريات

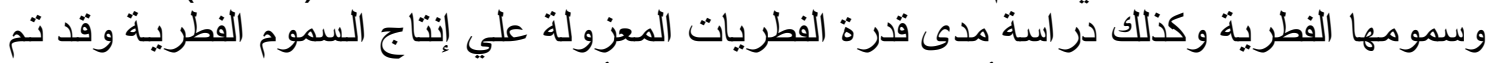

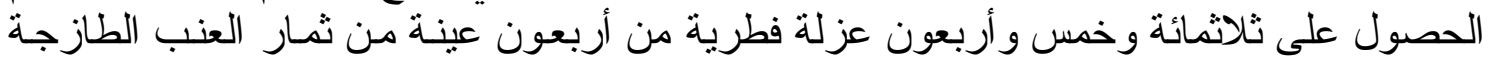

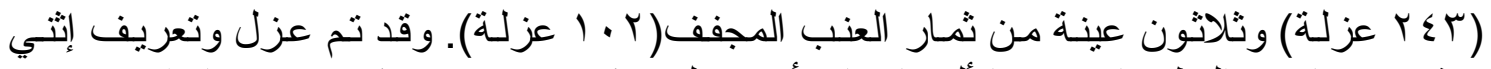

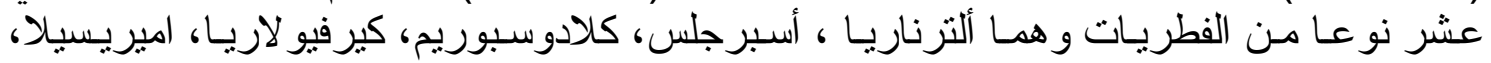

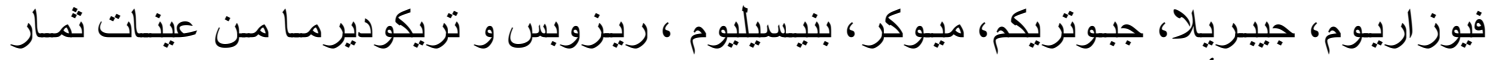

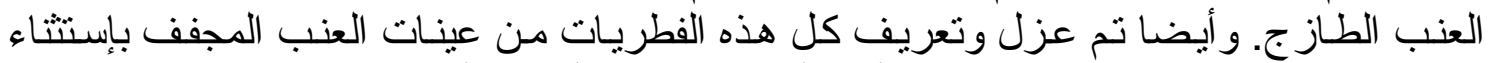

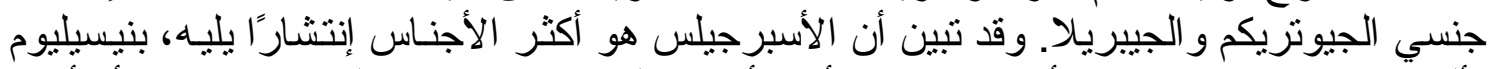

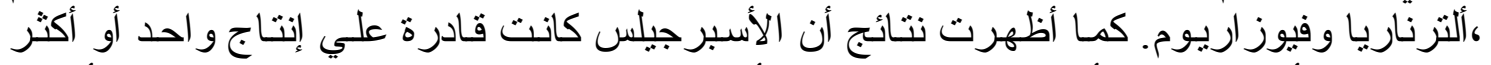

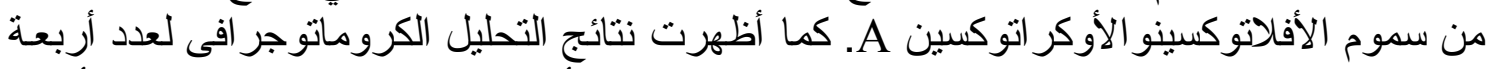

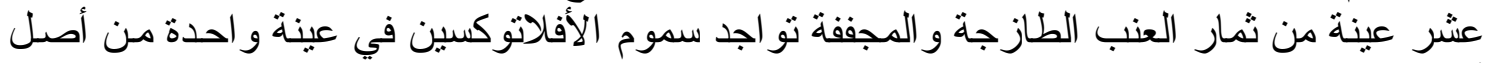

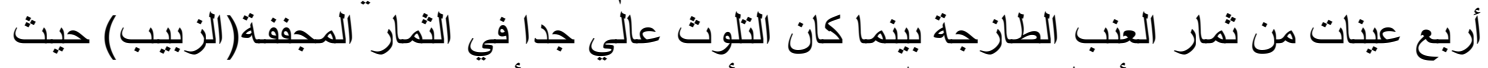
إحتوت سبع عينات من أصل عشرة علي سموم الأفلاتوكسينو الأوكر اتوكسين. 